\title{
ANALYSIS OF THE PROPOSED \$18.40 LIVING WAGE
}

\author{
Anita King \\ New Zealand Treasury
}

\begin{abstract}
Over the last two years, a campaign has been running to pay employees a "living wage" of $\$ 18.40 / \mathrm{hr}$ (recently increased to $\$ 18.80 / \mathrm{hr}$ ). Using cross-tabulations of data from the Household Economic Survey 2010/11, this work looks at who in New Zealand is currently receiving wages below this level, by age, family type, education level, industry, gender, and ethnicity. This group has proportionately higher numbers of people who are under 30, or who are single adults without dependents. It does not take into account labour supply and demand effects, nor does it consider wage relativity effects on those currently earning above the living wage. We also calculate the increase in disposable income for a variety of different family types if they were to increase their wages from the minimum wage to the living wage, and find that those that are currently receiving the most government assistance (usually families with dependent children) benefit the least from this increase due to the abatement of that assistance.
\end{abstract}

\section{Introduction}

In 2012, the Living Wage Aotearoa New Zealand Campaign was launched in New Zealand to introduce a "living wage" of $\$ 18.40 / \mathrm{hr}$ (King and Waldegrave, 2012). This was proposed as a wage that a family with one full-time and one part-time earner and two dependent children could live on "with dignity and to participate as active citizens in society" (p.3, King and Waldegrave, 2012). It followed similar campaigns in the UK, Australia, Canada, and other countries. This living wage is not intended to be enshrined in legislation as the minimum wage or as social welfare payments by government, but as a market tool to address low wages that could not support a family. Currently, 29 employers in New Zealand are Accredited Living Wage Employers (Living Wage, 2015), and other organisation including Wellington City Council (Chapman, 2013) are committed to implementing it.

Paper Scope

In this paper some characteristics of those in New Zealand earning below the living wage are determined. It does not make any normative judgements on those characteristics. In addition, the level of the living wage is taken as given for the purposes of this paper, and no attempt is made to analyse or comment on its basis or adequacy for a certain standard of living. Scott (2014) has provided a recent critique of the method used to determine the level of the living wage.

The flow-on effects to other wages and other parts of the economy should a living wage be widely adopted are also not considered in this paper. There are also several effects that are not included in this analysis that are likely to be important and should be taken into account before any living wage is implemented at a national level: 
- Wage relativity, where those who are earning a little above the living wage are keen to retain their relative wage differentials to those who were earning below the living wage.

- Potential for increased inflation due to increased wage levels.

- Changes to labour supply. Higher wage rates can incentivise working more hours, but they can also incentivise a drop in hours worked. This dual effect was illustrated in work evaluating changes to Working for Families by Mok and Mercante (2014).

- Incentives on educational attainment. New Zealand already has relatively low returns to tertiary education (Zuccollo et al., 2013), and increasing the wage levels of lower income earners who typically have lower educational attainment may further reduce these returns.

- Changes to labour demand. In theory, wage increases can lead to increased unemployment, although the evidence for this is weak. The scale of the increase in unemployment is also difficult to estimate as this is not a marginal change.

\section{Contents}

This paper continues by discussing distribution of the increase in income between the government and families moving up to a living wage, then the data and methodology used. The results section then describes the characteristics of the people who earn less (and more) than the living wage and makes up the bulk of the paper.

\section{Who benefits from increasing wages to the living wage level?}

When market incomes are increased, a portion of that increase is paid to the government in the form of income taxes and the abatement of government transfers, with the remainder going to the person who earned that income. This will be the case for people who receive a pay rise from their current income (below the living wage) up to the living wage.

For individuals working 40 hours per week, the minimum wage of $\$ 13.75 / \mathrm{hr}$ in $2013 / 14$ gives a gross market income of $\$ 28,600$ per annum, and the living wage of $\$ 18.40 / \mathrm{hr}$ give a gross market income of $\$ 38,272$ per annum. An increase from the minimum wage to the living wage would result in extra gross market income of $\$ 9,672$ per annum, or $\$ 186$ per week. The proportion of this paid to the government will depend on the level of the increase, the general tax rate, and the specific support the family was getting from the government including Working for Families and the Accommodation Supplement.

All individuals who receive an increase in income will pay more income tax. In New Zealand, income tax has a progressive structure with different rates for different absolute income levels. For full-time workers with no other sources of income, an increase in their wage to the living wage will be taxed at $17.5 \%$, plus a $1.7 \%$ ACC contribution.

A small number of people who are working part-time may also be receiving a core benefit such as the Domestic Purposes Benefit (now replaced by Sole Parent Support). Their benefit will be abated at the legislated rate (typically about 70\%) until they no longer receive it. While they are receiving a benefit, their income will be lower than the abatement thresholds for other types of support, so they will only face benefit abatement and income tax. 
Most people who are earning below the living wage and have children will be eligible for Working for Families assistance. Full-time workers on the living wage will be above the abatement threshold for this payment, and so their Working for Families tax credit will be abated at (currently) $21.25 \%$ of their increase in gross income.

Some households with lower incomes will also be eligible for the Accommodation Supplement, based on their rent/mortgage, income, and household income. Full-time workers on the living wage are also likely to be above the abatement threshold for this payment, and so Accommodation Supplement transfer will be abated at $25 \%$ of their increase in gross income.

There are a variety of other government transfer payments that are also abated in the income range between benefit levels and the living wage, such as the Temporary Additional Support that families may be receiving. As several of these abatements occur concurrently, a large proportion of the extra income from an increase in wages from the current level to the living wage rate will be paid to the government in the form of income tax and transfer abatement. This is calculated for some specific situations in Figure 1.

Figure 1: Effect of increasing wage to $\$ 18.40 / \mathrm{hr}$ living wage for government and families (Treasury, 2013)

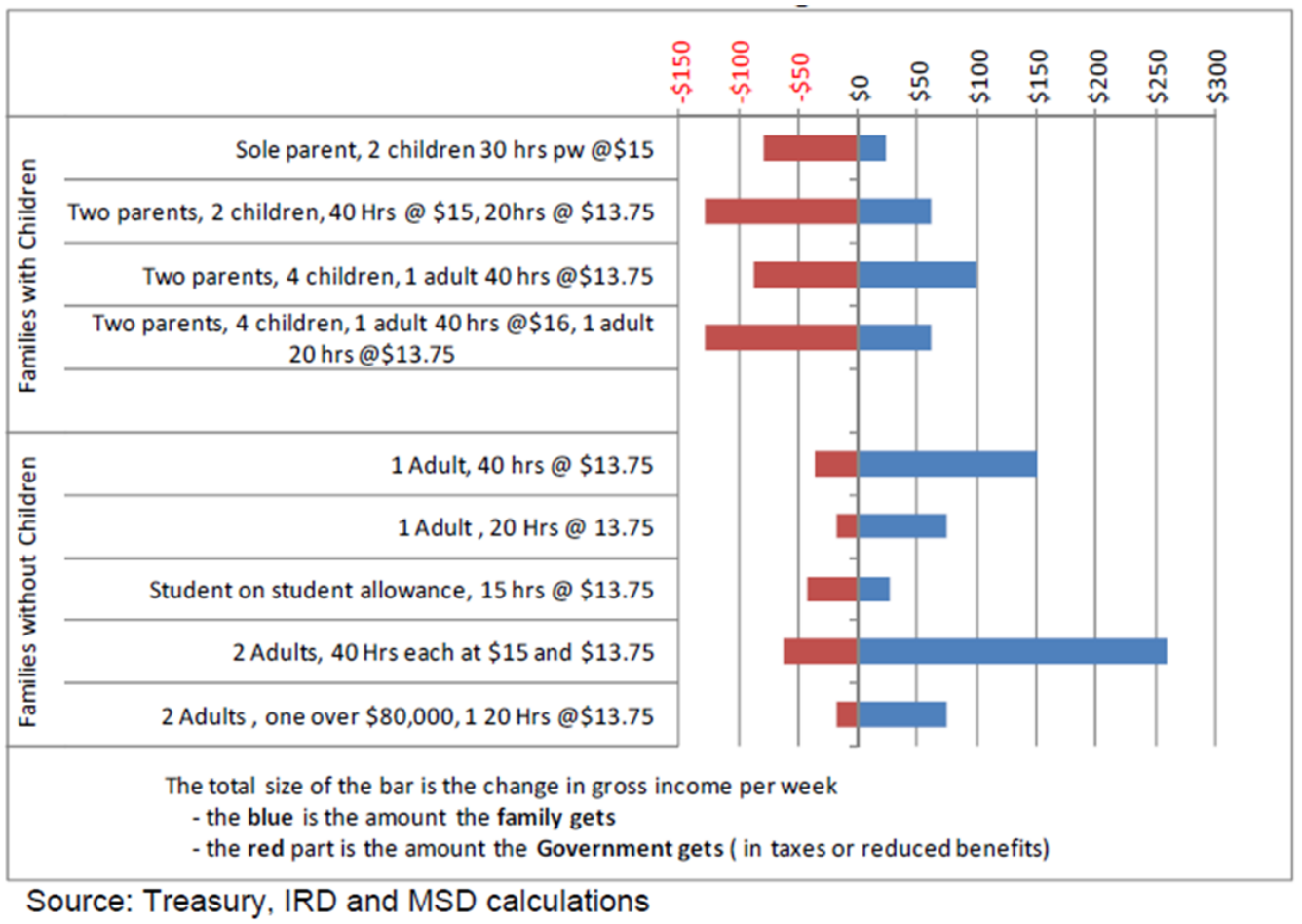

Notice that families with children retain much less of the gross increase in income - they face an effective tax rate of roughly $66 \%$ on the increase in income. This is primarily due to the abatement of the Working for Families tax credit and the Accommodation Supplement. New Zealand's welfare system is designed to use government transfers to redistribute income towards families, but the living wage uses employers to distribute income towards individuals irrespective of family status. As Figure 1 illustrates, a movement towards paying employees the living wage moves emphasis away from the redistributive transfers to families of the current welfare system. 


\section{Data and Method}

The data used for this paper is unit record data from the Household Economic Survey (HES) 2010/11 (see (Statistics NZ, 2014) for a description), processed for use in the New Zealand Treasury's Taxwell microsimulation model. This survey had 9,000 individuals of all ages, living in 3,536 households, and the small sample size restricts the level of detail that can be studied with statistical meaningfulness. At the time the analysis for this paper was performed, this was the most recent data that had been processed for use in Taxwell, and the living wage rate was set at $\$ 18.40 / \mathrm{hr}$.

This processing includes forming economic family units, which consist of one adult, their adult partner if in the survey, and any dependent children (based on the Working for Families definition) recorded in the survey. Weights for each household in the survey are also estimated and benchmarked to a number of demographic totals for New Zealand as well as the numbers of people receiving core benefits such as the unemployment benefit. These weights are closely related to the weights calculated by Statistics New Zealand, but include additional benchmarks for benefits. However, apart from inflating incomes to 2013/14 dollars, calculations from the actual Taxwell model have not been used for this analysis, as the processed HES data provided sufficient information.

HES records the hours and income from multiple jobs (both current and previous) in the twelve months before the interview separately for each person. To simplify this analysis, only one wage for each person is calculated. In this analysis, it is done by using the current wage/salary job with the most hours for each person. Note that if a person has both a self-employment job and a wage/salary job, only the wage/salary job will be considered even if more hours were worked in the self-employed job.

In addition, only people who have current wage/salary jobs are included in this analysis people who are self-employed, living solely on benefit income or investment income, or not in the workforce (including dependent children) are not included. Figure 2 below shows the number of people in New Zealand who are not earning wage/salary income (unwaged) and excluded from this analysis, and the number of people earning wages below and above the living wage who are included in this analysis. Note that the number of people earning wages or salaries is only a portion of the total workforce, and the unwaged category includes everyone else in New Zealand including children, the elderly, and people supported by other members of their household or the government. 
Figure 2: New Zealand population of people earning above and below the living wage

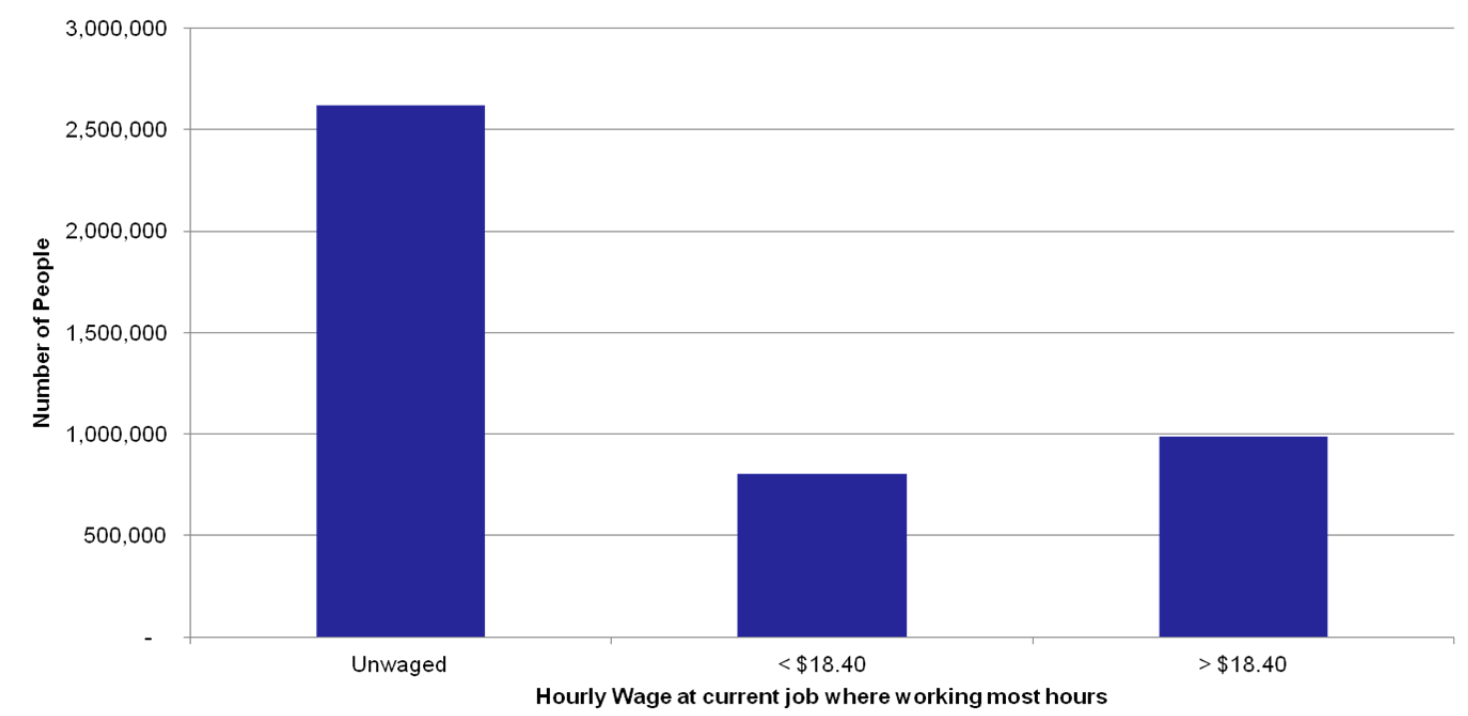

While this method of calculating individual wages works well for most people, there are certain groups where it is likely to under-represent the income or wage of the individual. Individuals may have additional income from commissions and other non-wage/salary remuneration, selfemployment, investment, or sharing income earned by their partners. As it is difficult to consistently identify these groups in the data, they are included in the results of the analysis, which must then be interpreted accordingly.

The method used for this analysis is simple. Once wages are calculated as described above, the population of waged individuals is separated into those earning above and those earning below the $\$ 18.40$ living wage. This is then further divided (separately) by each category used in the results - age, family type, education level, industry of employment, gender, and ethnicity. No attempt is made to account for correlations between these categories (which are highly likely to exist), nor to determine causality.

\section{Characteristics of people who earn less than the living wage}

There are two ways of looking at the results presented below, represented by the first and second graphs in each section. The first graphs (Figure 3Figure 5Figure 7Figure 9Figure 11Figure 13) show the percentage of people that are earning below (above) the living wage in each category. This essentially shows a population-weighted view including the characteristics of the typical person earning below (above) the living wage. The second graphs (Figure 4Figure 6Figure 8Figure 10Figure 12Figure 14) show the percentage of people in each category who earn below the living wage, which indicates whether that category has more people earning below the living wage than average.

\section{Age}

Figure 3 shows that $30 \%$ of the people who earn below the living wage are aged 20-29. By contrast, about $30 \%$ of people earning above the living wage are aged $40-49$, and another $30 \%$ are aged 30-39. People under 20 and over 60 do not make up a large proportion of either group, as they make up a smaller part of the population of people earning wage and salary income in New Zealand. 
Figure 3: Proportion of people in each age group earning below and above the living wage

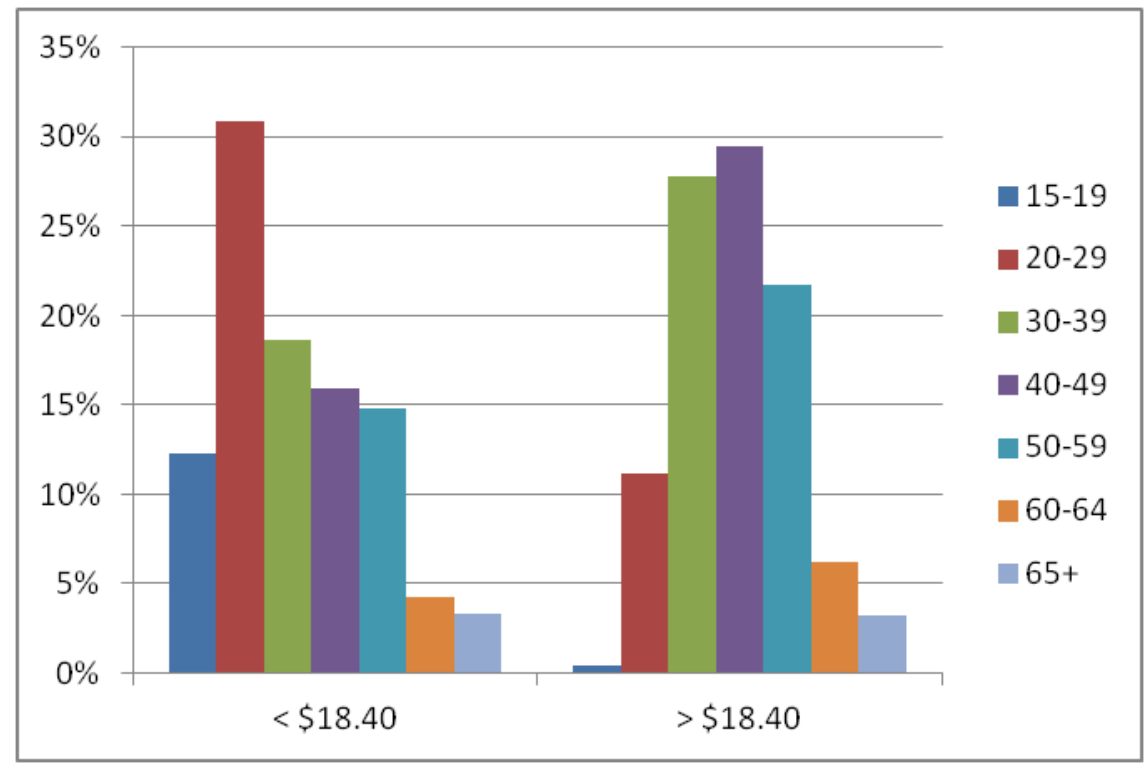

Figure 4 shows most people under 30 earn less than the living wage, and very few teenagers earn above the living wage. By contrast, most people between 30 and 65 earn more than the living wage. This is consistent with literature such as Ball and Creedy (2013) on life-cycle earnings where the usual trajectory for (male) incomes is that they start low, increase rapidly during the first decade or two of working life, then increase more slowly after that and decline slightly around retirement age.

Figure 4: Proportion of people earning below the living wage by age group

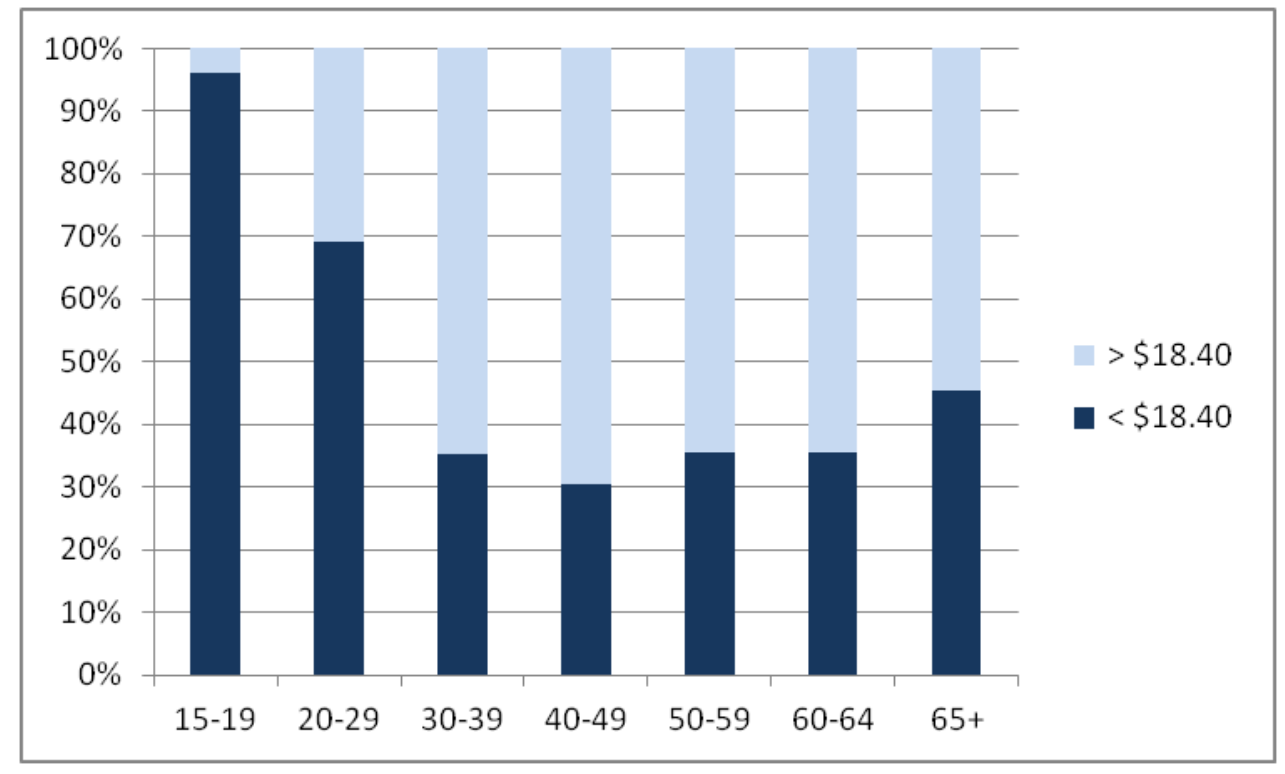

\section{Family Type}

In this dataset, families are formulated as economic family units. They are defined as an adult, plus their adult partner if they exist, and any of their dependent children; all living in the same household. Thus, there are either one or two adults in each family, but any number of dependent children. Children are defined as dependent if they are under 15 or if they are under 
19 and meet certain conditions regarding education and income. Adult children are defined as separate families even if living in the same household as their parents. Dependent children living in different households are not included.

Based on this definition, family types based on the number of adults and dependent children can be defined. Families are said to be earning more than the living wage if the person earning the most income in the family is earning more than the living wage. Figure 5 shows that the typical family earning below the living wage is comprised of a single adult with no dependent children. This is due to the combination of a large number of single-adult families in the population and the dominance of that group by younger adults who were shown earlier to be over-represented in those earning less than the living wage.

Figure 5: Proportion of families in each family type earning below and above the living wage

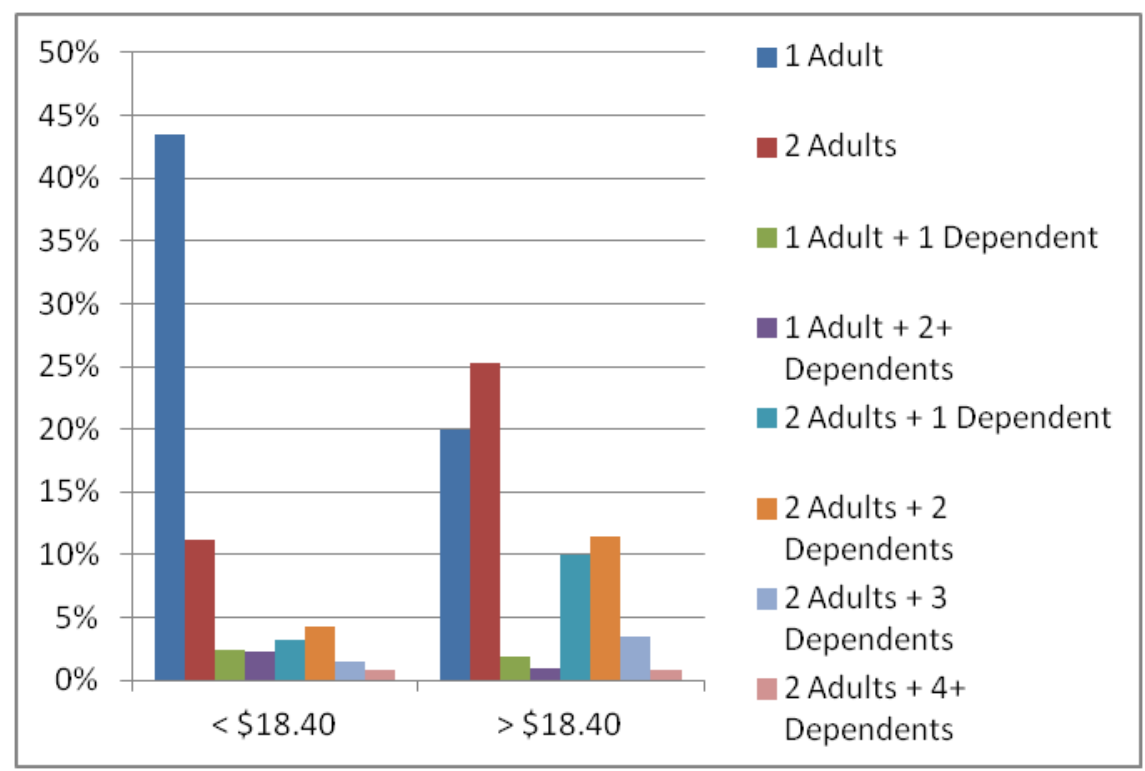

Figure 6 shows that single adults and sole parents with more than one dependent child are more likely to be earning below the living wage. Families with two adults are more likely to be earning above the living wage, unless they have more than three dependent children. Note these values are not adjusted for age. 
Figure 6: Proportion of families earning below the living wage by family type

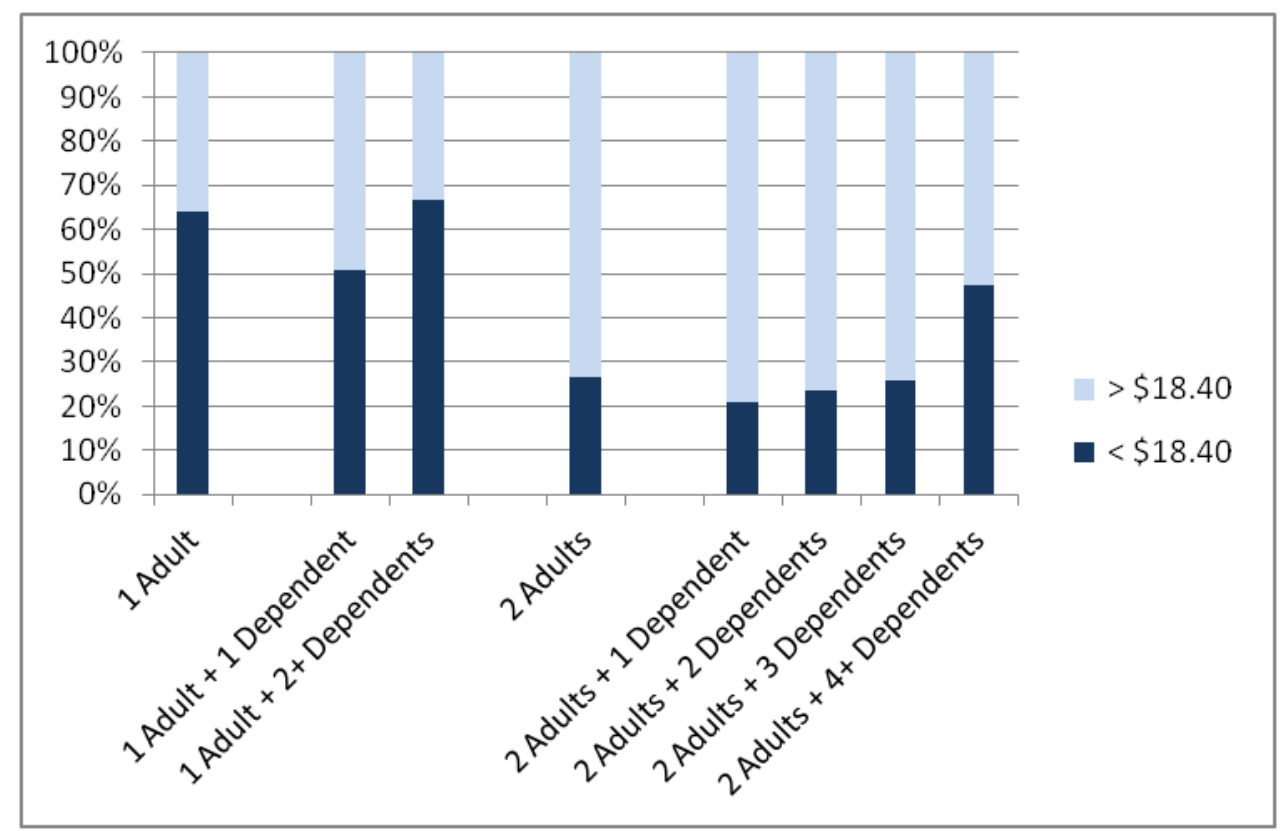

\section{Education Level}

Figure 7 shows that people who have a level 1-3 Certificate, which is the most basic school level qualification distinguished, are the largest group (about 35\%) earning less than the living wage. By contrast, people with a level 4-6 or other post-school qualification make up about $35 \%$ of people earning above the living wage. This is partially because people with this qualification level (including people who have completed apprenticeships or earned diplomas) make up a large part of the population.

Figure 7: Proportion of people at each education level earning below and above the living wage



Figure 8 show that most people without post-school qualifications are earning below the living wage, whereas most people with a post-school qualification are earning more than the living wage. Again, these results are not adjusted for age. 
Figure 8: Proportion of people earning below the living wage by education level

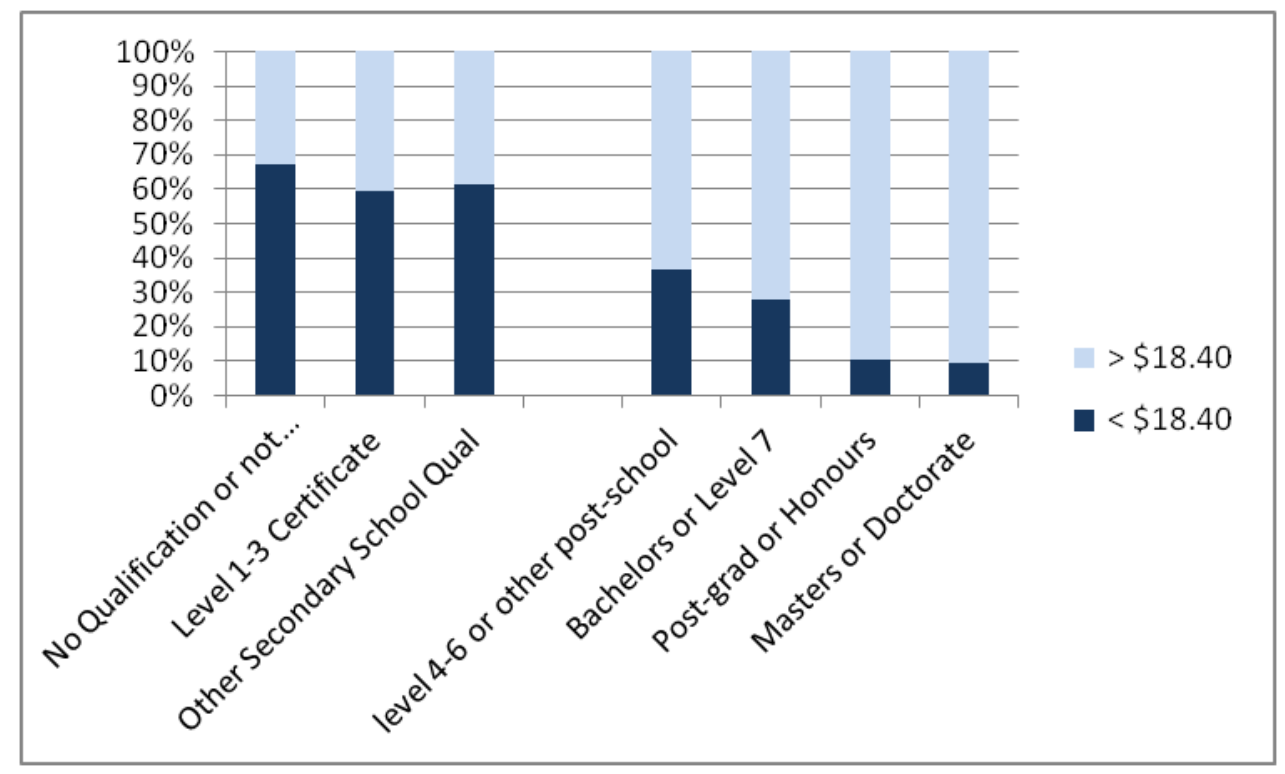

Industry

A large number of industries are represented in the data, so their ANZSIC abbreviations are used in the graphs so that the categories remain readable. The description of each category is given in Table 1.

Table 1: ANZSIC abbreviations for industries as used in graphs

$\begin{array}{ll}\text { A } & \text { Agriculture, Forestry and Fishing } \\ \text { C } & \text { Manufacturing } \\ \text { E } & \text { Construction } \\ \text { F } & \text { Wholesale Trade } \\ \text { G } & \text { Retail Trade } \\ \text { H } & \text { Accommodation and Food Services } \\ \text { I } & \text { Transport, Postal and Warehousing } \\ \text { J } & \text { Information Media and Telecommunications } \\ \text { K } & \text { Financial and Insurance Services } \\ \text { L } & \text { Rental, Hiring and Real Estate Services } \\ \text { M } & \text { Professional, Scientific and Technical Services } \\ \text { N } & \text { Administrative and Support Services } \\ \text { P } & \text { Education and Training } \\ \text { Q } & \text { Health Care and Social Assistance } \\ \text { R } & \text { Arts and Recreation Services } \\ \text { O, S } & \text { Other Services } \\ \text { B, D, T, None } & \text { Not Elsewhere Included or Not Given }\end{array}$

Figure 9 shows that about 55\% of people who earn below the living wage can be found in four industries: Retail Trade (G), Manufacturing (C), Accommodation and Food Services (H), and Health Care and Social Assistance (Q). About half of all people earning above the living wage can also be found in four industries: Other Services $(0, S)$, Education and Training (P), Health Care and Social Assistance $(\mathrm{Q})$, and Manufacturing (C). The Manufacturing and the Health Care and 
Social Assistance industries are both large employers, which partially explains why they make up a larger portion of both the above-living-wage and below-living-wage groups.

Figure 9: Proportion of people in each industry earning below and above the living wage



Figure 10 shows that more than $75 \%$ of people who work in the Accommodation and Food Services (ANZSIC code H) and the Retail Trade (G) industries earn below the living wage, whereas less than $20 \%$ of people who work in the Financial and Insurance Services $(\mathrm{K})$ and the Professional, Scientific and Technical Services (M) industries earn less than the living wage. 
Figure 10: Proportion of people earning below the living wage by industry

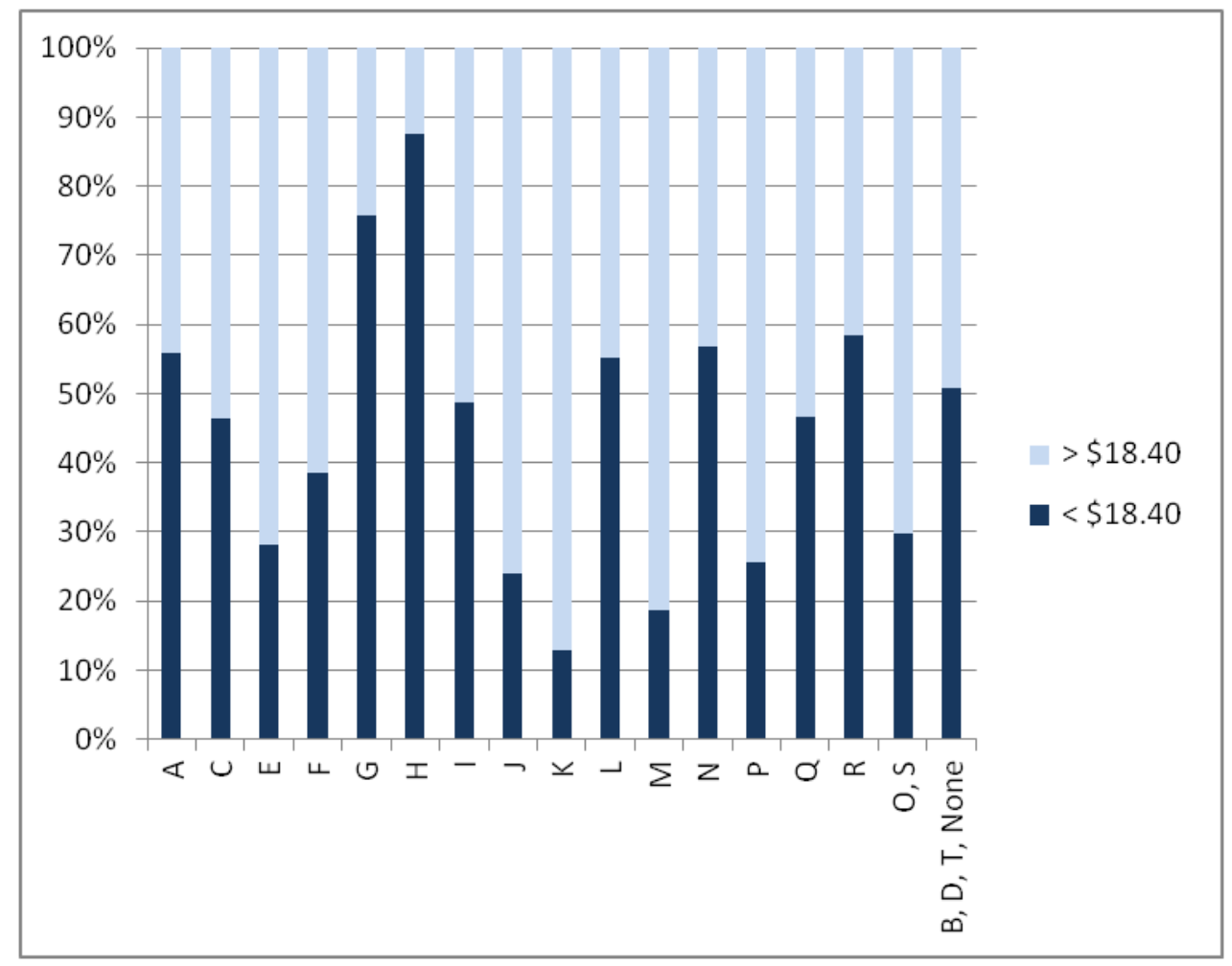

\section{Gender}

While Figure 11 appears to show that most people earning below the living wage are female, and most earning above are male, the difference between the two genders is small and unlikely to be statistically significant given the small sample size used to estimate these results.

Figure 11: Proportion of people of each gender earning below and above the living wage

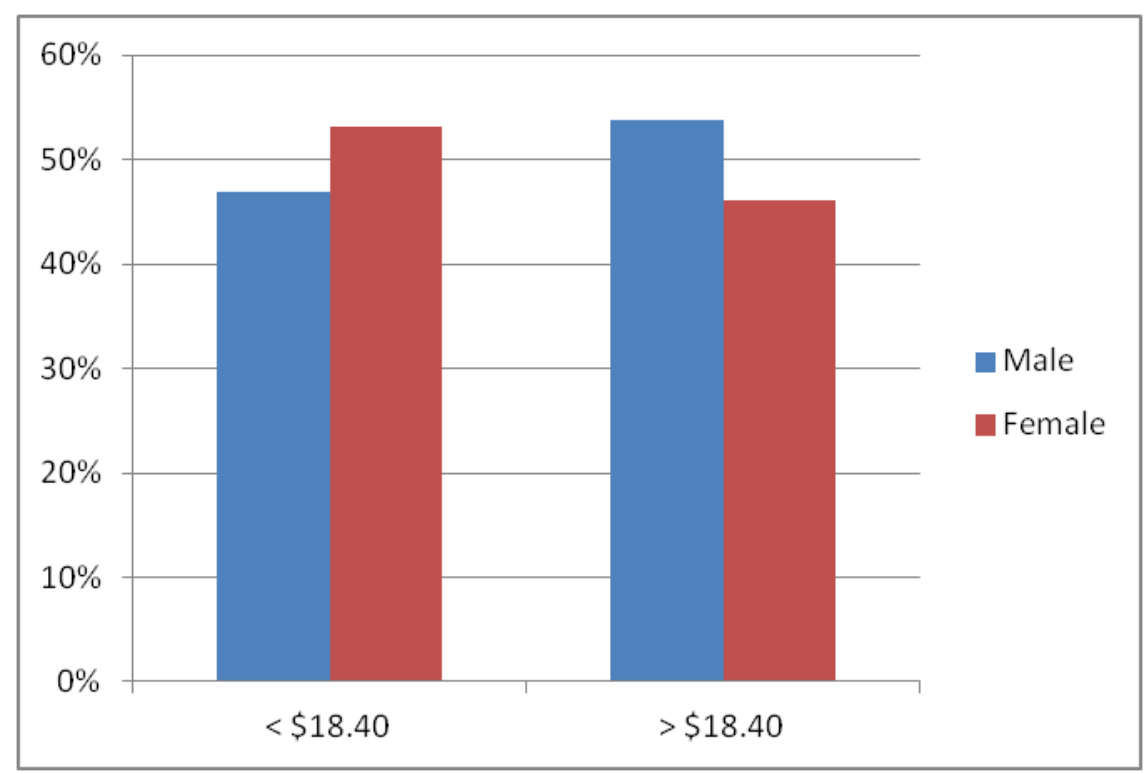

Figure 12 shows that most people - male or female - earn more than the living wage. This is due to more people overall earning above the living wage than below it (as shown in Figure 2), and little difference between the genders. 
Figure 12: Proportion of people earning below the living wage by gender

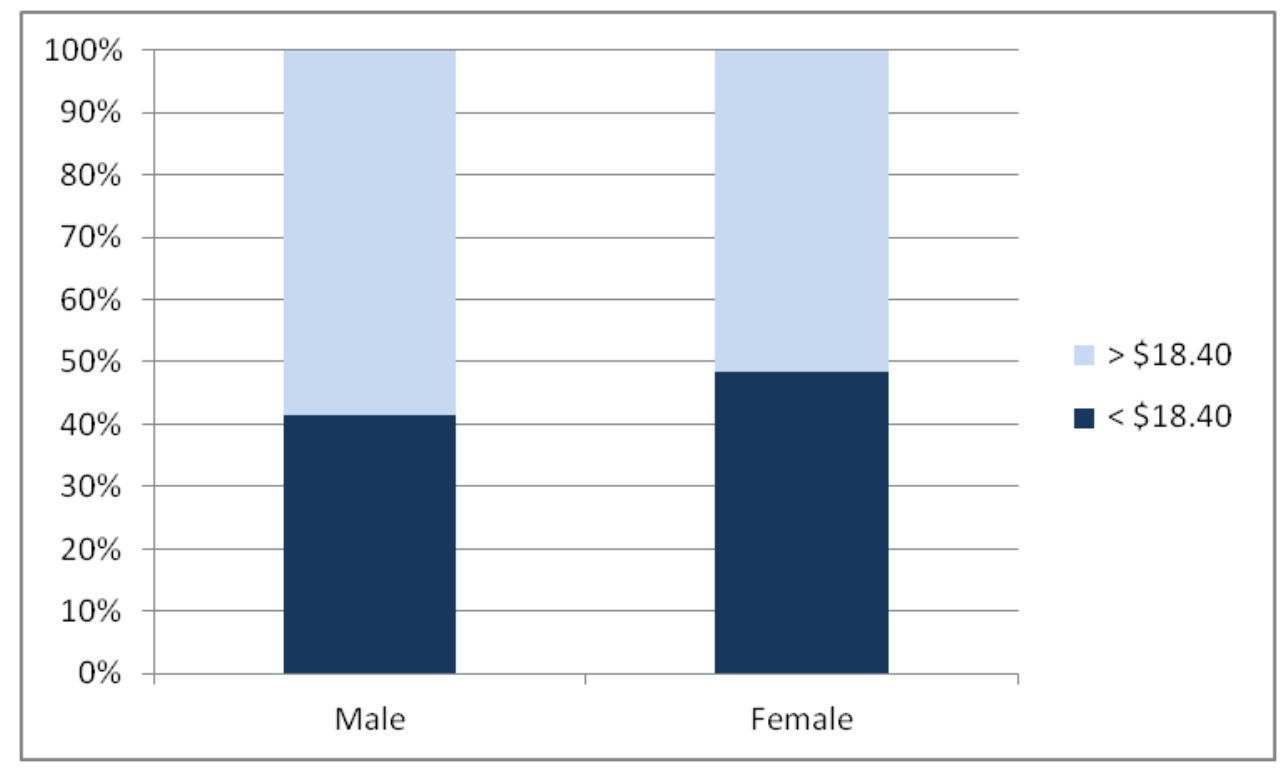

\section{Ethnicity}

The HES survey uses self-reported ethnicity, and survey respondents can report multiple ethnicities. In this section, ethnicities have been grouped as shown in Table 2.

Table 2: Ethnicity groupings

\begin{tabular}{ll}
\hline Grouped Ethnicity & Reported in HES \\
\hline European & European only \\
& European + Other \\
\hline European-Māori & European + Māori \\
& European + Māori + Pacific \\
& European + Māori + Other \\
& European + Māori + Pacific + Other \\
\hline Māori & Māori only \\
& Māori + Pacific \\
& Māori + Other \\
& Māori + Pacific + Other \\
\hline Pacific & Pacific only \\
& Pacific + European \\
& Pacific + Other \\
& Pacific + European + Other \\
\hline Other & Other only \\
\hline
\end{tabular}

Figure 13 shows that most people who earn below the living wage are European. This is because the vast majority of the New Zealand population is of European ethnicity. 
Figure 13: Proportion of people of each ethnicity earning below and above the living wage

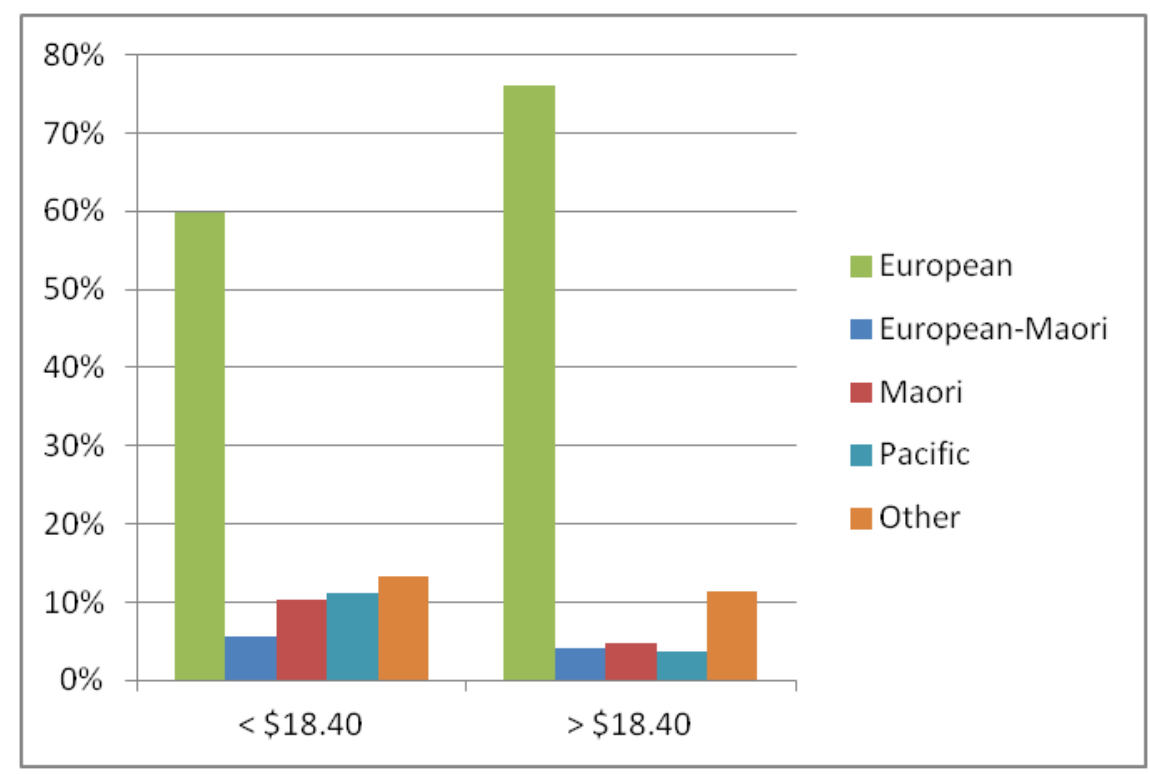

However, Figure 14 shows that most Māori and Pacific people earn below the living wage, and most Europeans earn above the living wage. This will be partly related to the younger age of people reporting Māori and Pacific ethnicity. It is the only result given in this paper where the typical person earning below the living wage does not overlap with the groups of people who are more likely to be earning below the living wage.

Figure 14: Proportion of people earning below the living wage by ethnicity

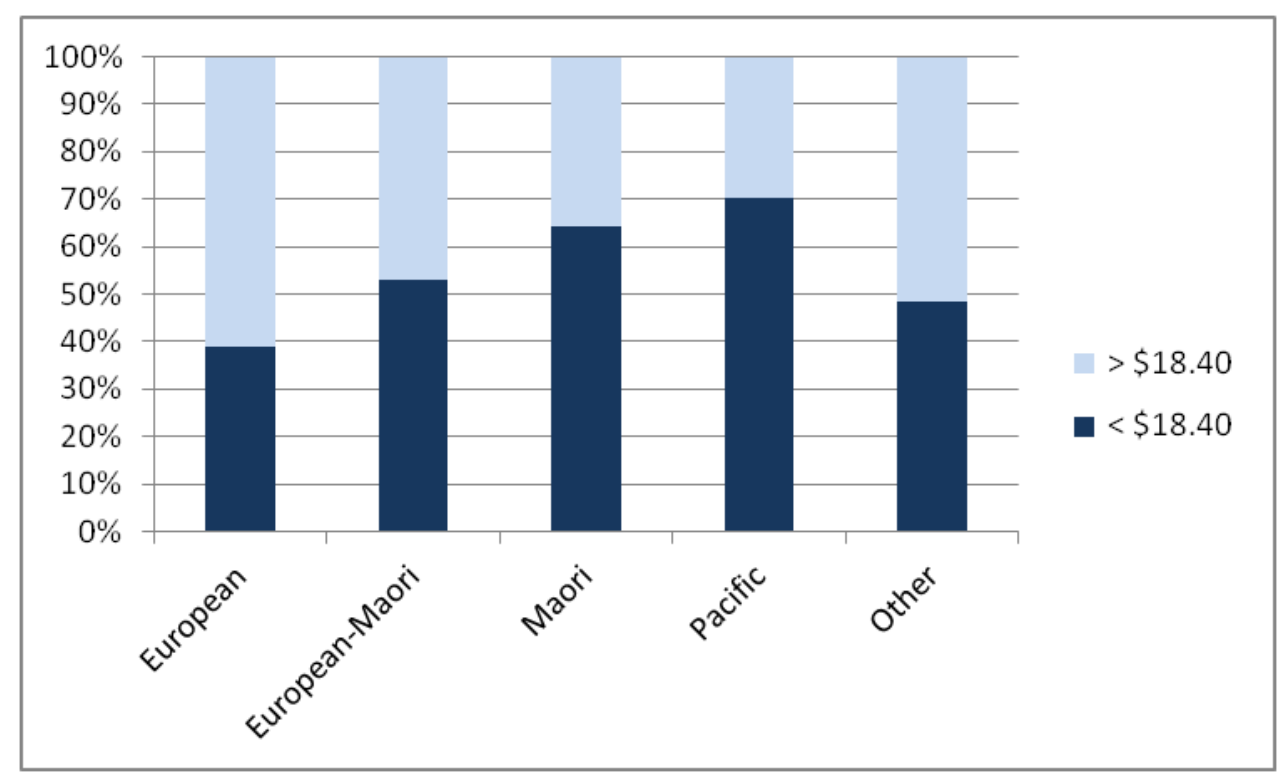

\section{Conclusion}

A typical person who earns less than the living wage is 20-29 years old, single with no children, has low qualifications, works in works in accommodation and food services, retail trade, or manufacturing, could be male or female, and is European. A person earning less than the living wage is more likely than average to be under 30 years old, be a single adult or a sole parent, have no post-school qualifications, work in accommodation and food services or retail trade, and of Māori or Pacific ethnicity. Apart from ethnicity, the typical person earning less than the living 
wage is very similar to the person who is over-represented among those earning less than the living wage.

Note that many of these characteristics are correlated with each other, and particularly with age. Younger people are more likely to be single with no children. People who work in the accommodation and food services, retail trade, and the manufacturing industries tend to have lower qualifications.

Although this analysis does not attempt to determine causality, these results are useful for targeting policy responses and other action for increasing wages. Several questions need to be asked for each group however:

1. Is it acceptable that this group earns less than the living wage? The answer to this will depend on the values of the person answering, but may, for example, conclude that it is more acceptable for younger people (with less experience) to be earning less than the living wage than it is for older people (with more experience).

2. Do the recipients need this level of income? Some groups, for example those with more children or living in areas of high housing costs may need more, and some groups such as young single students may need less.

3. Will the living wage increase the disposable income of the family, or will most of the benefit accrue to the government? Are there other ways that would increase the disposable income of the family more effectively?

It is also important to note that families will receive significantly less benefit to increasing wages up to the living wage level than couples and individuals without children. This is primarily because New Zealand's welfare system redistributes income to families, but a living wage benefits individual incomes. Because of this change in emphasis, less income is redistributed to families and they face high effective tax rates on their increased incomes.

There are several ways this work can be taken forward. The simplest is to update the analysis using the new living wage value of $\$ 18.80 / \mathrm{hr}$ (King and Waldegrave, 2014) and the latest data from HES or other surveys that have wage information. Other ways of slicing the data can also be used. Beyond this, an econometric analysis would allow the cross-correlations between the different variables, such as age and family type, to be taken into account. Other living wage levels could be investigated, as could the behavioural effects of the living wage on labour supply. Taking this further, a general equilibrium analysis would allow flow-on effects such as inflation and labour demand at the new wage level to be taken into account, although caution needs to be applied as some of the assumptions in these models are only valid for marginal changes to parts of the economy, not the large changes described here.

\section{Acknowledgements}

The author would like to thank various Treasury analysts for their helpful comments on the paper and for checking the analysis.

Access to the Household Economic Survey data was provided by Statistics New Zealand under conditions designed to give effect to the security and confidentiality provisions of the Statistics Act 1975. The work presented here is that of the author, not Statistics New Zealand. 


\section{References}

Ball, C. and Creedy, J. (2013) Population Ageing and the Growth of Income and Consumption Tax Revenue, Treasury Working Paper, http://www.treasury.govt.nz/publications/research-policy/wp/2013/13-09

Chapman, K. (2013) Wellington to be a living wage capital, Stuff.co.nz, http://www.stuff.co.nz/dominion-post/news/wellington/8787413/Wellington-to-be-aliving-wage-capital

King, P. and Waldegrave, C. (2012) Report of an investigation into defining a living wage for New Zealand, Family Centre Social Policy Research, http://www.familycentre.org.nz/Publications/PDF's/Living Wage Investigation Report 2 013.pdf?PHPSESSID=1cc83fc8552c66351e22fd7b644c7900

King, P. and Waldegrave, C. (2014) Living Wage Aotearoa New Zealand 2014 Update, Family Centre Social Policy Research, http://www.familycentre.org.nz/Publications/PDF's/Living Wage 2014 Report.pdf?PHP $\underline{\text { SESSID }=12400 \mathrm{e} 6 \mathrm{bf} 46 \mathrm{f} 9844 \mathrm{cfc} 00 \mathrm{fbc} 7750662 \mathrm{c}}$

Living Wage Aotearoa New Zealand (2015) Accredited Living Wage Employers in New Zealand, http://www.livingwage.org.nz/accredited living wage employers in $\mathrm{nz}$, accessed 7 January 2015

Mok, P. and Mercante, J. (2014) Working for Families changes: The effect on labour supply in New Zealand, Treasury Working Paper, http://www.treasury.govt.nz/publications/research-policy/wp/2014/14-18

Statistics NZ (2014) Household Economic Survey and Household Economic Survey (Income), http://www.stats.govt.nz/browse for stats/people and communities/Households/house hold-economic-survey.aspx

Scott, B. (2014) A Review into the Basis for a Living Wage Rate in New Zealand (With additional material), http://www.nzcpr.com/wp-content/uploads/2014/03/A-Review-into-theBasis-for-a-Living-Wage-Rate-in-New-Zealand-by-Brian-Scott.pdf

Treasury (2013) Analysis of the Proposed $\$ 18.40$ Living Wage, http://www.treasury.govt.nz/publications/informationreleases/livingwage

Zuccollo, J., Maani, S., Kaye-Blake, B. and Zeng, L. (2013) Private Returns to Tertiary Education - How does New Zealand Compare to the OECD?, Treasury Working Paper, http://www.treasury.govt.nz/publications/research-policy/wp/2013/13-10 